\title{
Management of soft rot of banana caused by Erwinia carotovora sub sp. Carotovora
}

\author{
MALLIKARJUN KENGANAL ${ }^{1 *}$, YUSUF ALI NIMBARAGI ${ }^{2}$ AND G. S. GURUPRASD ${ }^{3}$ \\ ${ }^{1}$ Department of Plant Pathology, University of Agricultural Sciences, RAICHUR (KARNATAKA) INDIA \\ ${ }^{2}$ Agricultural Extension Education Centre, KOPPAL (KARNATAKA) INDIA \\ ${ }^{3}$ AICRP on Rice, Agricultural Research Station, GANGAVATI (KARNATAKA) INDIA
}

\section{ARITCLE INFO}

Received : 09.07 .2017

Revised : 30.08 .2017

Accepted : 12.09 .2017

\section{KEY WORDS :}

Banana, Soft rot, Erwinia carotovora, Management, Drenching

*Corresponding author: Email : mallikarjun_nss@ rediffmail. com

\begin{abstract}
:
Banana a fruit of poor and rich is source of food and fibre. It has multiple uses of its all plant parts. However, its cultivation is hampered by many diseases like in other crops. The least known soft rot disease among farmers caused by Erwinia carotovora subsp. Carotovora has become a threat to banana cultivation. The present study was aimed to identify suitable control measures of soft rot to avoid plunging banana yield. A field experiment was conducted for two years during 2014 and 2015 by imposing eight different treatments with three replications on 25 plants in each treatment in an orchard severely affected by soft rot. Results obtained were statistically analysed and yield was subjected to cost benefit ratio analysis. Among the treatments imposed, drenching and foliar spray of copper oxychloride 50WP at $3 \mathrm{~g} / 1+$ streptomycin sulphate $0.5 \mathrm{~g} / \mathrm{l}$ at 15 days interval, beginning from 15 days after planting and application of bleaching powder $25 \mathrm{~g} / \mathrm{plant} / \mathrm{month}$ two inches away from pseudostem around the collar region upto four months was found most effective and recorded lowest soft rot disease incidence of 7.67 per cent during 2014 and 9.28 per cent during 2015. This treatment also recorded highest bunch yield of $32.9 \mathrm{~kg} / \mathrm{plant}$ during $2014,30.03 \mathrm{~kg} / \mathrm{plant}$ during 2015 . The pooled disease incidence was 8.47 per cent and yield of $31.47 \mathrm{~kg} / \mathrm{plant}$. This treatment showed highest cost benefit ratio of 3.54 compared to control which had 1.6. Neither copper oxychloride nor the streptomycin sulphate alone or in combination could give better results as earlier reported. But their mixed application both by drenching and foliar spray had better impact and most effective when coupled with application of bleaching powder. The results conclude effective control of soft rot can be done without compromising the yield by following best treatment of the experiment.
\end{abstract}

How to view point the article : Kenganal, Mallikarjun, Nimbaragi, Yusuf Ali and Guruprasd, G. S. (2017). Management of soft rot of banana caused by Erwinia carotovora sub sp. Carotovora. Internat. J. Plant Protec., 10(2) : 381-385, DOI : 10.15740/HAS/IJPP/10.2/381-385. 